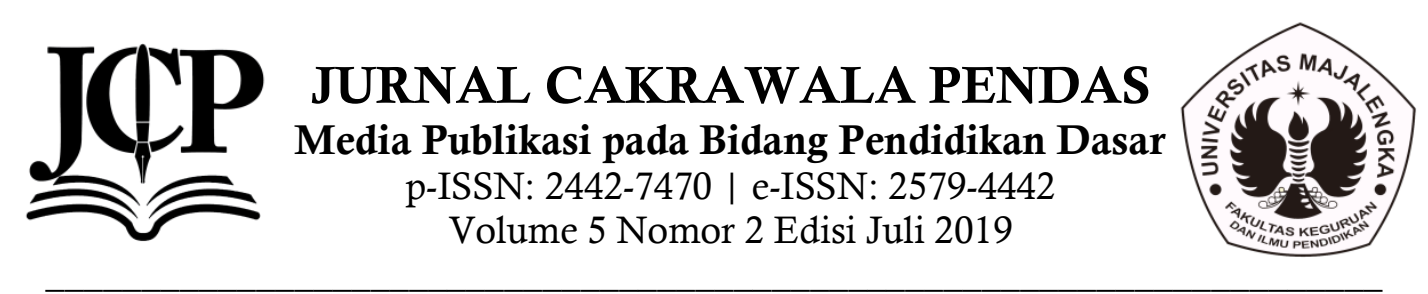

\title{
MODEL PEMBELAJARAN PROBLEM POSING DALAM MENINGKATAN KEMAMPUAN BERPIKIR KRITIS
}

\author{
Ujiati Cahyaningsih ${ }^{1}$, Ayu Herlina ${ }^{2}$ \\ ${ }^{1}$ Universitas Majalengka, ${ }^{2}$ Universitas Majalengka \\ 'ujiati.cahyaningsih@gmail.com
}

\begin{abstract}
Abstrak
Penelitian ini didasari oleh rendahnya kemampuan berpikir kritis siswa kususnya pada pembelajaran IPA. Penelitian ini merupakan penelitian tindakan kelas yang bekerjasama dengan guru kelas V SD Negeri Genteng II Kecamatan Dawuan Kabupaten Majalengka. Siswa kelas V berjumlah 37 siswa dengan 16 siswa perempuan dan 21 siswa laki-laki. Upaya meningkatkan kemampuan berpikir kritis siswa pada penelitian ini adalah dengan menerapkan model pembelajaran Problem Posing yaitu pada materi daur air. Teknik yang digunakan dalam pengumpulan data pada penelitian ini adalah tes, pengamatan dan dokumentasi. Instrumen yang digunakan terdiri dari lembar evaluasi (butir soal), lembar observasi kegiatan siswa, lembar observasi kegiatan guru dan foto. Data yang diperoleh berupa hasil tes dan hasil pengamatan sebagai data primer serta dokumentasi sebagai data sekunder. Teknik analisis data yang digunakan adalah analisis deskriptif kuantitatif untuk menganalisis tes akir setiap siklus dan analisis deskriptif kualitatif untuk hasil observasi setiap siklus. Penelitian ini dilaksanakan dalam dua siklus dengan menggunakan desain penelitian yang mengacu pada Kemmis dan Mc Taggart. Hasil penelitian menunjukkan penggunaan model pembelajaran Problem Posing dapat meningkatkan kemampuan berpikir kritis siswa. Terbukti pada pra-siklus rata-rata kelas hanya 64,29 dengan presentase ketuntasan belajar siswa mencapai $24,32 \%$. Pada siklus I nilai rata-rata kelas menjadi 68,89 dengan presentase $51,35 \%$. Pada siklus II nilai rata-rata kelas 77,78 dan presentase ketuntasan siswa $83,78 \%$. Dengan demikian, penggunaan model pembelajaran Problem Posing dapat meningkatkan kemampuan berpikir kritis siswa pada siswa kelas V SD Negeri Genteng II.
\end{abstract}

Kata Kunci: Berpikir Kritis, Model pembelajaran Problem Posing, Pembelajaran IPA 


\section{Pendahuluan}

Pendidikan

memanusiakan

adalah proses

manusia dan

mengembangkan potensi yang ada dalam diri manusia itu sendiri. Seperti yang dijelaskan dalam Undang-Undang Nasional Sistem Pendidikan Nasional pasal 1 ayat 1 No. 20 tahun 2003 (dalam Majid, 2014: 1) bahwa pendidikan bertujuan untuk mengembangkan potensi siswa dengan pembelajaran, bimbingan dan latihan guna membentuk karakter yang baik dan berakhlak mulia sehingga mengarahkan siswa menjadi sumber daya manusia yang berkualitas. Mengembangkan potensi siswa harus dimulai sejak usia dini, yakni pada usia sekolah dasar. Salah satu pelajaran yang dipelajari sejak sekolah dasar adalah Ilmu Pengetahuan Alam (IPA). Idealnya proses pembelajaran IPA harus menekankan pada pemberian pengalaman langsung untuk mengembangkan kompetensi agar menjelajahi dan memahami alam sekitar secara ilmiah.

Dalam implementasi di lapangan pembelajaran IPA masih belum terlaksana dengan baik. Sesuai dari hasil observasi yang telah penelitilakukan pada tanggal 28 Maret 2018 di SDN Genteng II pada kelas $\mathrm{V}$ siswa belum sepenuhnya memahami pembelajaran IPA. Terbukti saat peneliti melakukan pre-test pada mata pelajaran IPA khususnya materi daur air diperoleh hasil yaitu $24,32 \%$ atau 9 siswa dari 37 siswa yang dapat mencapai Kriteria Ketuntasan Minimal (KKM), dan sisanya adalah siswa yang tidak mencapai nilai Kriteria Ketuntasan Minimal (KKM) yaitu sebesar $75,67 \%$ atau 24 siswa dari 37 siswa.

Menurut Abidin (2016: 167) mengatakan bahwa berpikir kritis merupakan upaya untuk mengolah pengetahuan sebagai sarana mencari solusi untuk mmecahkan suatu masalah tertentu. Lau (dalam Abidin 2016: 171) menjelaskan bahwa pembelajaran yang bertujuan meningkatkan kemampuan berpikir krritis adalah adanya tantangan bagi siswa. Tantangan yang diterapkan harus disesuaikan dengan perkembangan psikologis, minat, dan motivasi siswa.

Ada beberapa model pembelajaran yang digunakan dalam pembelajaran IPA, salah satu model yang dimungkinkan dapat mendukung tercapainya tujuan pembelajaran serta meningkatkan kemampuan berpikir kritis siswa adalah model Problem Posing. Model pembelajaran Problem Posing merupakan salah satu alternatif model yang diharapkan dapat mengatasi permasalahan-permasalah di atas serta dapat meningkatkan kemampuan berpikir kritis siswa. "Pada intinya dalam model pembelajaran Problem Posing meminta siswa untuk mengajukan soal atau masalah. Soal yang diajukan dapat berdasarkan pada topik yang luas, masalah yang dikerjakan, atau informasi tertentu yang diberikan oleh guru" (Shoimin, 2014: 133). Menurut Thobroni \& Mustofa (2012: 356) menyatakan bahwa keterlibatan siswa untuk turut belajar dengan menerapkan model pembelajaran Problem Posing merupakan salah satu indikator keefektifan belajar. Siswa tidak hanya menerima materi dari guru tetapi juga berusaha menggali dan mengembangkan informasi terhadap suatu permasalahan.

Berdasarkan uraian di atas, dilaksanakan perbaikan pembelajaran melalui penelitian tindakan kelas dengan tujuan meningkatkan kemampuan berpikir kritis siswa pada pembelajaran IPA melalui penerapan model Problem Posing pada siswa kelas V SD Negeri Genteng II.

\section{Metode Penelitian}

Penelitian ini menggunakan Classroom Action Research atau yang lebih familiar disebut Penelitian Tindakan Kelas (PTK). Desain penelitian yang dilakukan mengacu pada skema yang dikemukakan oleh Kemmis dan Mc Taggart. Arikunto (2015: 16) merumuskan pembelajaran yang akan dilaksanakan pada skema yang dikemukakanan Kemmis dan Mc Taggart yaitu melalui tahap (1) perencanaan, (2) pelaksanaan, (3) observasi, (4) refleksi.

Penelitian ini dilaksanakan pada semester genap dengan jangka waktu 3 minggu terhitung dari tanggal 04 April hingga 18 April 2018. Subjek penelitian ini adalah siswa kelas V SD Negeri Genteng II. Jumlah siswa tersebut adalah 37 siswa, yang terdiri dari 16 perempuan dan 21 siswa laki-laki. 
Data-data yang berkaitan dengan penelitian dikumpulkan melalui dua teknik, yakni tes, non tes dan dokumentasi. Teknik tes digunakan untuk mengukur hasil belajar kognitif siswa melalui tes formatif. Sedangakan teknik non tes digunakan untuk mengukur variabel berupa aktivitas siswa dan kinerja guru menggunakan lembar observasi. Dokumentasi ini berbentuk foto-foto kegiatan selama penelitian berlangsung. Teknik analisis data menggunakan teknik analisis kualitatif dan kuantitatif. Analisis kualitatif digunakan untuk menganalisis data kinerja guru, aktivitas siswa, hasil belajar afektif, dan psikomotor selama proses pembelajaran berlangsung. Sedangkan analisis kuantitatif digunakan untuk menganalisis data hasil belajar kognitif.

\section{Hasil Penelitian}

Hasil kegiatan guru (peneliti) pada siklus I tindakan I memperoleh presentase sebesar $63,33 \%$ kemudian pada tindakan II sebesar $76,67 \%$ dan meningkat lagi pada siklus II tindakan I sebesar 83,33\% kemudian pada tindakan II meningkat lagi menjadi 93,33\%. Terlihat adanya peningkatan disetiap siklusnya sehingga dapat disimpulkan bahwa guru selalu mengalami peningkatan pada saat melakukan kegiatan mengajar. Untuk lebih jelasnya mengenai hasil observasi kegiatan guru dapat dilihat pada tabel 1 di bawah ini:

Tabel 1

Presentase Hasil Observasi Guru Siklus I dan Siklus II

\begin{tabular}{ccccc}
\hline \multirow{2}{*}{ Aspek } & \multicolumn{2}{c}{ Siklus I } & \multicolumn{2}{c}{ Siklus II } \\
\cline { 2 - 5 } & $\begin{array}{c}\text { Tinda } \\
\text { kan I }\end{array}$ & $\begin{array}{c}\text { Tindak } \\
\text { an II }\end{array}$ & $\begin{array}{c}\text { Tind } \\
\text { akan } \\
\text { I }\end{array}$ & $\begin{array}{c}\text { Tinda } \\
\text { kan II }\end{array}$ \\
\hline Presentase & $\begin{array}{c}63,33 \\
\%\end{array}$ & $\begin{array}{c}76,67 \\
\%\end{array}$ & $\begin{array}{c}83,33 \\
\%\end{array}$ & $\begin{array}{c}93,33 \\
\%\end{array}$ \\
\hline $\begin{array}{c}\text { Peningkata } \\
\mathrm{n}\end{array}$ & $13,34 \%$ & \multicolumn{2}{c}{$10 \%$} \\
\hline Kategori & Baik & \multicolumn{2}{c}{ Sangat Baik } \\
\hline
\end{tabular}

Agar lebih jelas, peneliti sajikan gambar mengenai perbandingan peningkatan presentase hasil observasi guru di siklus I dan siklus II pada gambar 1 di bawah ini:

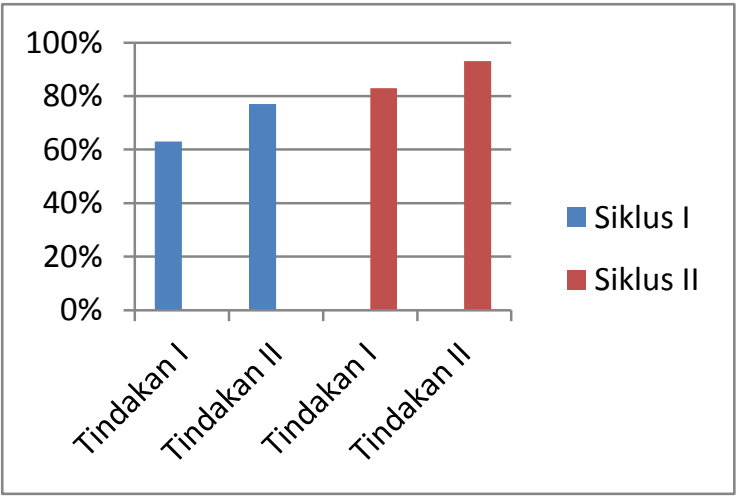

Gambar 1

Presentase Hasil observasi Kegiatan Guru Siklus I dan II

Sedangkan hasil kegiatan siswa pada siklus I tindakan I memperoleh hasil sebesar $66,67 \%$ kemudian pada tindakan II sebesar 77,78\% dan pada siklus II tindakan I masih sama yaitu $77,78 \%$ kemudian meningkat kembali pada tindakan II yaitu sebesar $88,89 \%$. Adapun gambar presentase kegiatan siswa dapat dilihat pada tabel 2 di bawah ini:

Tabel 2

Presentase Hasil Observasi Siswa Siklus I dan Siklus II

\begin{tabular}{lcccc}
\hline \multirow{2}{*}{ Aspek } & \multicolumn{2}{c}{ Siklus I } & \multicolumn{2}{c}{ Siklus II } \\
\cline { 2 - 5 } & $\begin{array}{c}\text { Tinda } \\
\text { kan I }\end{array}$ & $\begin{array}{c}\text { Tindak } \\
\text { an II }\end{array}$ & $\begin{array}{l}\text { Tindak } \\
\text { an I }\end{array}$ & $\begin{array}{l}\text { Tindak } \\
\text { an II }\end{array}$ \\
\hline $\begin{array}{c}\text { Presenta } \\
\text { se }\end{array}$ & $\begin{array}{c}66,67 \\
\%\end{array}$ & $\begin{array}{c}77,78 \\
\%\end{array}$ & $\begin{array}{c}77,78 \\
\%\end{array}$ & $\begin{array}{c}88,89 \\
\%\end{array}$ \\
\hline $\begin{array}{c}\text { Peningka } \\
\text { tan }\end{array}$ & & $11,11 \%$ & & $11,11 \%$ \\
\hline Kategori & Baik & & Sangat Baik \\
\hline
\end{tabular}

Presentase peningkatan hasil observasi siswa di siklus I dan siklus II dapat dilihat pada gambar 2 di bawah ini:

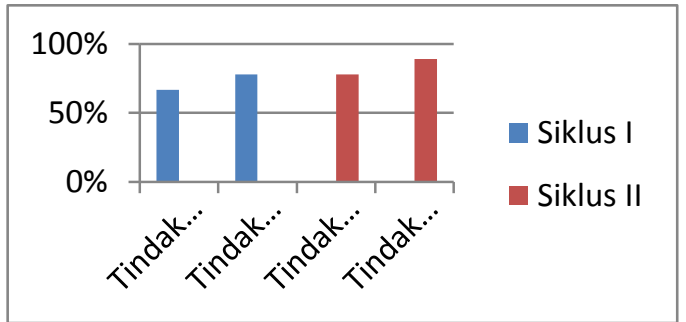

Gambar 2

Presentase Hasil observasi Kegiatan Siswa Siklus I dan II

Peningkatan nilai siswa pada prasiklus dengan persentase keberhasilan $24,32 \%$. Kemudian pada tes evaluasi siklus 
I diperoleh persentase keberhasilan $51,35 \%$, dan pada siklus II diperoleh persentase ketuntasan belajar mencapai $83,78 \%$.

Tabel 3

Presentase Ketuntasan Belajar Siswa

\begin{tabular}{llll} 
Aspek & Pra-Siklus & Siklus I & Siklus II \\
& & & \\
\hline Tuntas & $24,32 \%$ & $51,35 \%$ & $83,78 \%$ \\
\hline Belum Tuntas & $75,67 \%$ & $48,64 \%$ & $16,21 \%$ \\
\hline
\end{tabular}

Perbandingan peningkatan hasil evaluasi dapat juga disampaikan dalam bentuk grafik berikut ini:

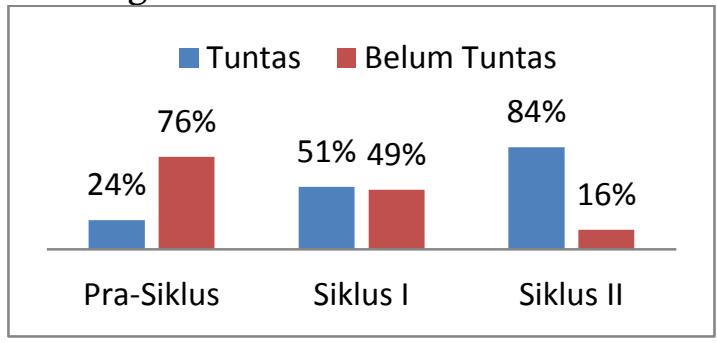

Gambar 3

Presentase Ketuntasan Belajar Siswa

Adapun presentase peningkatan yang terjadi pada pra-siklus ke siklus I, siklus I ke siklus II dan pra-siklus ke siklus II dapat dilihat pada tabel dibawah ini:

Tabel 4

Persentase Peningkatan

\begin{tabular}{|c|c|c|c|}
\hline $\begin{array}{l}\text { Persentase } \\
\text { Peningkatan }\end{array}$ & $\begin{array}{l}\text { Pra } \\
\text { Siklus } \\
\text { ke } \\
\text { Siklus I }\end{array}$ & $\begin{array}{l}\text { Siklus I } \\
\text { ke } \\
\text { Siklus II }\end{array}$ & $\begin{array}{l}\text { Pra } \\
\text { Siklus ke } \\
\text { Siklus II }\end{array}$ \\
\hline Persen & $7,14 \%$ & $13,02 \%$ & $21,10 \%$ \\
\hline
\end{tabular}

Untuk lebih jelasnya, peneliti sajikan presentase peningkatan antara pra-siklus hingga siklus I dan siklus II dapat dilihat pada gambar di bawah ini:

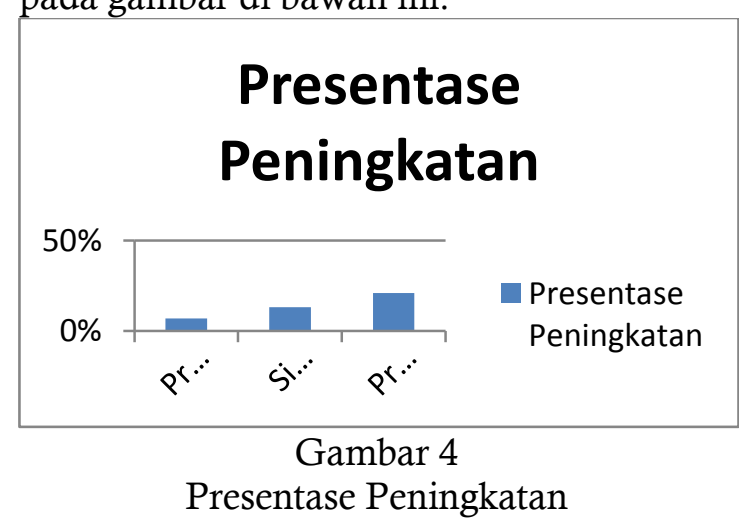

Presentase peningkatan belajar dari pra-siklus ke siklus I adalah sebesar 7,14\% sedangkan dari siklus I ke siklus II adalah sebesar 13,02\% dana presentase peningkatan dari pra-siklus ke siklus II sebesar $21,10 \%$.

Berdasarkan hasil penelitian menggunakan model pembelajaran Problem Posing selama dua siklus hasil yang diperoleh dari evaluasi siswa, observasi kegiatan siswa, maupun observasi kegiatan guru terus mengalami peningkatan dari siklus I ke siklus II.

Setelah dilakukan beberapa tindakan pada siswa kelas V SD Negeri Genteng II menggunakan model pembelejaran Problem Posing pada pembelajaran IPA materi daur air, kemampuan berpikir kritis siswa dapat meningkat. Penggunaan model pembelajaran Problem Posing dalam setiap tindakannya mengharuskan siswa untuk berpikir kritis dengan membuat pertanyaanpertanyaan sederhana berdasarkan pengalaman atau pengetahuan yang diterima dari penjelasan guru. Hal tersebut sesuai dengan pendapat dari Lau (dalam Abidin 2016: 171) bahwa pembelajaran yang bertujuan meningkatkan kemampuan berpikir kritis adalah adanya tantangan bagi siswa. Dapat disimpulkan bahwa penelitian ini telah berhasil meningkatkan kemampuan berpikir kritis siswa dengan hasil yang lebih baik dari setiap siklusnya, maka peneliti menyimpulkan bahwa dalam penelitian ini penerapan model pembelajaran Problem Posing dapat meningkatkan kemampuan berpikir kritis IPA pada materi daur air di kelas V SD Negeri Genteng II tahun ajaran 2017/2018.

\section{Kesimpulan}

Berdasarkan hasil penelitian yang telah di jelaskan dapat disimpilkan bahwa penelitian yang telah dilakukan dengan menerapkan model pembelajaran Problem Posing dalam meningkatkan kemampuan berpikir kritis siswa pada pembelajaran IPA di SDN Genteng II Kecamatan Dawuan Kabupaten Majalengka pada tahun ajaran 2017/2018 terbuki mengalami peningkatan. Hal tersebut dapat dilihat dari berbagai hasil yang didapatkan. Diantaranya, hasil observasi guru yang selalu meningkat pada 
setiap siklusnya dengan hasil akhir yang termasuk dalam kategori sangat baik. Begitupun dengan hasil observasi siswa yang mengalami peningkatan setiap siklusnya dengan hasil akhir termasuk dalam kategori sangat baik juga. Sedangkan pada hasil tes evaluasi siswa, peningkatan terjadi pada setiap siklusnya dengan hasil akhir presentase ketuntasan telah mencapai kriteria ketuntasan belajar siswa yang telah ditentukan sebelumnya.

Selain dari hasil observasi guru, hasil observasi siswa dan hasil tes evaluasi siswa, peningkatan yang terjadi pada penelitian ini dapat dilihat pula pada presentase peningkatan yang diperoleh dari pra-siklus ke siklus I yaitu sebesar $7,14 \%$, kemudian dari siklus I ke siklus II meningkat sebesar $13,02 \%$, sedangkan dari pra-siklus ke siklus II meningkat sebesar $21,10 \%$ Simpulan dapat bersifat generalisasi temuan sesuai permasalahan penelitian, dapat pula berupa rekomendatif untuk langkah selanjutnya.

\section{Daftar Pustaka}

Abidin, Y. (2016). Revitalisasi Penilaian Pembelajaran. Bandung: Refika Aditama.

Arikunto, dkk. (2015). Penelitian Tindakan Kelas. Jakarta: Bumi Aksara.

Majid, A. (2014). Pembelajaran Tematik Terpadu, Bandung: PT. Remaja Rosdakarya Offset.

Shoimin, A. (2014). 68 Model Pembelajaran Inovatif Dalam Kurikulum 2013, Yogyakarta: ARRUZZ MEDIA.

Thobroni, M dan Arif Mustofa. (2012). Belajar dan Pembelajaran: Pengembangan Wacana dan Praktik Pembelajaran dalam Pembengunan Nasional, Yogyakarta: Ar-ruzz Media. 